\title{
COACHING DAN KINERJA PERAWAT (STUDI KASUS PADA RUMAH SAKIT UMUM DAERAH CIBINONG, KABUPATEN BOGOR, JAWA BARAT)
}

\author{
Budi Hartono' ${ }^{1}$, Johanes Jakri², Komala Sari ${ }^{3}$ \\ ${ }^{1,3}$ STIKES Hang Tuah Pekanbaru Program Studi Magister Ilmu Kesehatan Masyarakat \\ ${ }^{2}$ Universitas Respati Indonesia Program PascasarjanaIlmu Kesehatan Masyarakat
}

\begin{abstract}
Background: Nurses can use coaching as the way to empower quality of their skillsto have excellent services in hospital. Coaching is a tool that can improve motivation and performance of nurses. The research is aimed to get explanation about the relation of coaching, motivation and performance at a regional hospital. Method: Methodology research is correlationalcrosssectionalstudy with 30 nurses as respondents. Path analysis are used as statistical tools. Result: The result of this study shows that $R^{2}$ is about 0.704; it means that coaching has a direct, positive and significant impact to motivation and performance of nurses. Motivation has a direct, positive and significant impact to the performance of the nurses $(R$-value $=0.848)$. Coaching has an indirect, positive and significant impact to the performance of nurse through job motivation $(R-$ value $=$ 0.737). Conclusion: Conclusions of this study is coaching can increase nurse potential related to work motivation, coaching aims at increasing the potential of nurses who are performance oriented. Planning, implementation and evaluation of empowerment programs with effective coaching methods can ultimately improve the quality and accountability of nurses performance. Result of this research implied that the use of coaching could improve motivation and performance for nurse in hospital.
\end{abstract}

Keywords: Coaching, Motivation, Performance, Nurses

\section{PENDAHULUAN}

Dalam menghadapi era Masyarakat Ekonomi Asia (MEA), aspek kesehatan akan menjadi sektor utama dalam mendukung pembangunan bangsa. Rumah Sakit (RS) sebagai institusi pelayanan kesehatan harus memiliki sumber daya manusia (SDM) yang kompetitif dan berkualitas. Kualitas sumber daya manusia yang dimiliki oleh RS sangat berpengaruh terhadap kinerja dan kualitas layanan kesehatan yang dihasilkan. Ini menentukan bahwa petugas kesehatan memiliki peran penting untuk meningkatkan kualitas kesehatan masyarakat. Petugas kesehatan (dalam hal ini perawat) memiliki posisi penting dalam menghasilkan layanan kesehatan berkualitas di RS. Menurut Joint Commission International (2002) tentang elemen penilaian akreditasi RS yang menyatakan bahwa setiap pendidikan karyawan, pelatihan in-service yang berkelanjutan dan lain sebagainya adalah cara (metode) untuk mempertahankan atau meningkatkan keterampilan maupun pengetahuan mereka. Oleh karena itu, pengadaan, pendidikan dan pelatihan tenaga kesehatan harus dikembangkan untuk memenuhi standar kompetensi dan daya saing yang diharapkan, baik secara nasional maupun internasional.

Fenomena pelayanan kesehatan dengan bahaya yang tinggi merupakan 
salah satu keunikan dalam industri pelayanan kesehatan. Studi dari Institute of Medicine (IOM) menemukan bahwa setiap tahun diperkirakan sekitar 44.00098.000 pasien meninggal di pusat-pusat pelayanan kesehatan Amerika Serikat. Di Inggris, Denmark dan Australia menemukan insiden tersebut diperkirakan berkisar antara 3,2\% hingga 16,6\%. Di Indonesia, juga digolongkan besar namun beberapa ahli percaya bahwa dibutuhkan lebih banyak penelitian untuk menilai masalah yang paling penting seperti halnya keselamatan pasien ini (Kohn \& Corrigan, 2000). Survei yang dilakukan oleh Indonesian Corruption Watch (ICW) pada tahun 2009 menyatakan bahwa masih banyak layanan kesehatan tidak memberikan kepuasan kepada pasien, seperti ketidakramahan karyawan, kebersihan yang masih rendah, konflik karyawan sehingga mempengaruhi proses layanan, dan juga waktu layanan yang tidak akurat. RSUD Cibinong sebagai institusi pelayanan kesehatan juga menghadapi masalah yang sama dimana dalam era Jaminan Kesehatan Nasional $(\mathrm{JKN})$ ini hasil survei internal didapat bahwa tingkat kepuasan pasien secara total adalah sebesar $60 \%$ yang mana hal ini masih belum sesuai dengan target standar pelayanan minimal yaitu sebesar $80 \%$. Masalah ini tentu saja terkait dengan kompetensi dan kualitas SDM yang dimiliki oleh RS. Peningkatan kompetensi dalam program pemberdayaan diharapkan memberikan nilai bagi sumber daya manusia sehingga motivasi dan kinerja dapat ditingkatkan dan dikembangkan.

Menurut Jane Smith dalam Hartono (2016), ada tiga tingkat pemberdayaan dimana semakin tinggi tingkat pemberdayaan maka semakin baik manfaat yang diberikan kepada organisasi, yaitu: (1) encouraging, mendorong staf untuk lebih aktif dalam pekerjaan, (2) involving, melibatkan staf dalam mengambil tanggung jawab untuk meningkatkan cara melakukan sesuatu dan (3) enabling, memungkinkan staf untuk membuat keputusan yang lebih besar tanpa ketergantungan pada tingkat senior. Terkait dengan upaya untuk memberdayakan staf, metode yang dapat digunakan adalah pelatihan, mentoring, konseling dan coaching. Salah satu metode yang dapat digunakan oleh manajer untuk melakukan bimbingan adalah coaching (Whitemore, 2009). Perbedaan antara coaching dan metode lainnya adalah coaching memiliki fokus untuk mendapatkan berbagai kemungkinan jawaban bagi staf pada setiap masalah atau kondisi yang terjadi. Pada prinsipnya, metode coaching tidak memperbolehkan memberikan jawaban, saran, dan instruksi secara langsung kepada para peserta. Jika ingin memberikan saran, maka pernyataan atau perintah perlu dikemas dalam bentuk pertanyaan. Para pemimpin dan karyawan dapat menyadari pentingnya coaching dalam kegiatan bisnis perusahaan, sehingga mereka akan lebih intensif dalam melakukan coaching yang diharapkan akan mengarah pada peningkatan kinerja karyawan secara individu dan pada akhirnya berkontribusi secara signifikan terhadap keseluruhan kinerja organisasi (Arsendatama, 2016).

\section{METODE PENELITIAN}

Penelitian ini merupakan penelitian kuantitatif quasi eksperimen dengan desain pre-test dan post-test. Penelitian ini tidak menggunakan kelompok kontrol tetapi dilengkapi 
dengan pre-test untuk mengetahui dengan tepat efek dan pengaruh pelayanan yang dilakukan di Rumah Sakit Umum Daerah (RSUD) Cibinong, Kabupaten Bogor, Jawa Barat. Waktu penelitian adalah pada periode Mei hingga Juli 2016. Populasi penelitian adalah perawat karena memiliki jumlah terbesar yaitu 210 orang. Penentuan sampel menggunakan purposive sampling yaitu sekitar 30 orang. Sampel diambil untuk membuat daftar elemen atau anggota populasi secara acak dan kemudian membagi jumlah interval sampel yang diinginkan sehingga diperoleh dasar untuk penentuan sampling acak (Notoatmodjo, 2012).

Dalam proses penelitian, pengambilan data menggunakan data primer, peneliti menjelaskan studi yang dilakukan, termasuk tujuan dan apa yang diharapkan oleh responden. Setelah memberikan penjelasan penelitian, kemudian dilanjutkan dengan membagikan kuesioner pre-test yang bertujuan untuk mengukur motivasi dan kinerja perawat sebelum intervensi coaching dilakukan. Setelah kuesioner pre-test diisi oleh responden, kuesioner dikumpulkan dan peneliti memberikan penjelasan tentang pelatihan yang segera diikuti dengan memberikan sesi coaching kepada responden yang dibagi menjadi 6 kelompok dimana masing-masing kelompok berisikan 5 orang perawat. Sesi coaching diadakan dalam kelompok (group coaching), dengan menggunakan model coaching "GROW" yaitu Goal (tujuan), Reality (kenyataan), Options (pilihan) dan Way forward (jalan ke depan). Orang yang kompeten dalam coaching selanjutnya akan dipilih untuk melakukan sesi coaching. Setelah sekitar 45 menit hingga 1 jam per sesi coaching, peneliti membagikan kembali kuesioner post-test kepada responden untuk kemudian diisi oleh responden. Penelitian ini menggunakan variabel-variabel seperti motivasi, kinerja dan metodologi coaching. Para responden diminta mengisi kuesioner sesuai dengan apa yang mereka alami dan rasakan. Skala likert dari masing-masing variabel digunakan untuk menentukan skor jawaban responden terhadap kuesioner pre-test dan post-test. Analisis data dilakukan untuk semua variabel yang diukur dan dilakukan untuk menguji garis-garis model dengan menggunakan analisis jalur. Data ditampilkan menggunakan tabel yang menggambarkan hubungan dan pengaruh antar variabel. Penelitian ini telah memiliki izin institusi dengan nomor 011/IV/2016-Diklat. Keterbatasan penelitian ini adalah sesi coaching dilakukan oleh kelompok dan diperlakukan satu kali.

\section{HASIL PENELITIAN}

Untuk karakteristik responden dengan total sampel 30 orang dapat dilihat distribusi rata-rata usianya yaitu 26,7 tahun dengan rata-rata tingkat lama kerja 21,97 bulan. Untuk jenis kelamin, sebagian besar didominasi oleh wanita yaitu $73,3 \%$ sedangkan pada variable pendidikan sebesar 53,3\% adalah perawat berpendidikan diploma.

Hasil distribusi untuk pre-test dan post-test dapat ditunjukkan sebagaimana tabel bawah ini:

Tabel 1. Distribusi pre dan post-test

\begin{tabular}{lccc}
\hline Variabel & $\begin{array}{c}\text { Rata- } \\
\text { rata }\end{array}$ & $\begin{array}{c}\text { Standar } \\
\text { Deviasi }\end{array}$ & $\begin{array}{c}\text { P } \\
\text { Value }\end{array}$ \\
\cline { 1 - 3 } Pre-test: & & & \\
\cline { 1 - 2 } $\begin{array}{l}\text { Motivasi } \\
\text { Kerja }\end{array}$ & 55.60 & 10.11 & \multirow{2}{*}{0,00} \\
\cline { 1 - 2 } Kinerja & 27.60 & 2.75 & \\
\hline
\end{tabular}




\begin{tabular}{l}
\hline Post-test: \\
Motivasi 100.93 21,1 \\
Kerja \\
Kinerja 55.53 28,8 \\
Dari tabel di atas, dapat dilihat \\
perbedaan nilai rata-rata antara \\
pengukuran motivasi kerja sebelum \\
intervensi dilakukan (pre test) dengan \\
pengukuran motivasi kerja setelah \\
intervensi dilakukan (post test) yaitu \\
sebesar 45.33 dengan standar deviasi \\
sebesar 10.58 sehingga dapat disimpulkan \\
ada perbedaan yang signifikan antara pre- \\
test dengan post-test untuk pengukuran \\
motivasi kerja. Perbedaan antara nilai \\
rata-rata pengukuran kinerja perawat \\
sebelum intervensi dilakukan (pre-test) \\
dan pengukuran kinerja perawat setelah \\
intervensi dilakukan (post-test) adalah \\
sebesar 28.13 dengan nilai standar deviasi \\
sebesar 2,73 sehingga dapat disimpulkan \\
ada perbedaan yang cukup signifikan \\
antara pre-test dan post-test pada \\
pengukuran kinerja perawat. Tampak \\
bahwa terjadi peningkatan nilai rata-rata \\
dari variabel yang terkait dengan motivasi \\
dan kinerja sebelum dan sesudah tes \\
dilakukan.Ini menunjukkan bahwa \\
pekerjaan yang dilakukan setelah \\
menggunakan coaching adalah cukup \\
efektif.
\end{tabular}

\section{Model dan Persamaan Analisis Jalur}

Pengujian hipotesis dengan alat statistik dilakukan untuk menguji pengaruh Coaching (X) terhadap Motivasi Kerja (Y1) dan Kinerja Perawat (Y2) yaitu dengan menggunakan analisis jalur. Dalam penelitian ini, coaching (X) adalah sebagai variabel eksogen atau variabel penyebab, sedangkan motivasi kerja (Y1) dan kinerja perawat (Y2) adalah variabel endogen. Hasil perhitungan nilai korelasi antara variabel $\mathrm{X}$ dan variabel $\mathrm{Y} 1$ adalah sebesar 0,969 dan variabel $\mathrm{X}$ terhadap variabel $\mathrm{Y} 2$ sebesar 0,922. Ini menunjukkan bahwa ada hubungan yang sangat kuat antar variabel. Selanjutnya, koefisien jalur dapat diperoleh berdasarkan korelasi antara variabel koefisien jalur dari coaching (X) untuk motivasi kerja (Y1) dan kinerja perawat (Y2).

Dari perhitungan menggunakan program Analysis of Moment Structure (AMOS), ditemukan bahwa pengaruh coaching $(\mathrm{X})$ terhadap motivasi kerja (Y1) memiliki koefisien jalur ( $\rho y x)$ dengan tanda positif yang bernilai sebesar 42,76 $(\mathrm{p}=0,00)$, dan pengaruh coaching $(\mathrm{X})$ terhadap kinerja (Y2) memiliki koefisien jalur bertanda positif ( $\rho y y)$ dengan nilai $38.69(\mathrm{p}=0,000)$.

\section{Uji Struktural}

\section{a. Uji Secara Individual sub-} struktur 1

Hipotesis penelitian dirumuskan ke dalam hipotesis statistik sebagai berikut:

Ho: $($ pyx $)=0$ atau coaching tidak memiliki pengaruh positif dan signifikan langsung terhadap motivasi kerja.

Ha: (pyx)> 0 atau coaching memiliki pengaruh positif dan signifikan langsung terhadap motivasi.

Hasil sub struktur pengolahan data pertama, di mana nilai estimasi yang diilustrasikan antara variabel coaching dan motivasi adalah sebesar 42,77 dan untuk nilai korelasi regresi adalah sebesar 0,96 (bobot regresi terstandarisasi dengan nomor kelompok 1-model standar) dan nilai varians adalah sebesar 0,25 sedangkan nilai satuan kuadrat korelasi berganda adalah sebesar 0,93 sedangkan untuk 
motivasi (dengan e1) adalah sebesar 29,87 .

Hasil analisis dapat disampaikan bahwa koefisien sub struktur 1 diperoleh nilai sig 0,00 dimana nilainya lebih kecil dari nilai probabilitas $(0,05)$. Ini menyatakan bahwa Ha diterima dan Ho ditolak sedangkan koefisien analisis jalur signifikan. Hal ini menyatakan bahwa variabel coaching memiliki pengaruh positif dan signifikan langsung terhadap variabel motivasi kerja. Koefisien variabel coaching pada motivasi kerja sesuai dengan nilai koefisien yang dapat dilihat pada koefisien standar beta sub struktur 1 yaitu sebesar 0,96. Besarnya pengaruh sesuai dengan nilai $\mathrm{R}^{2}$ yaitu sebesar 93,9\%. Hubungan empirik sub struktur 1 adalah pengaruh variabel $\mathrm{X}$ terhadap Y1 dapat dilihat pada gambar berikut:

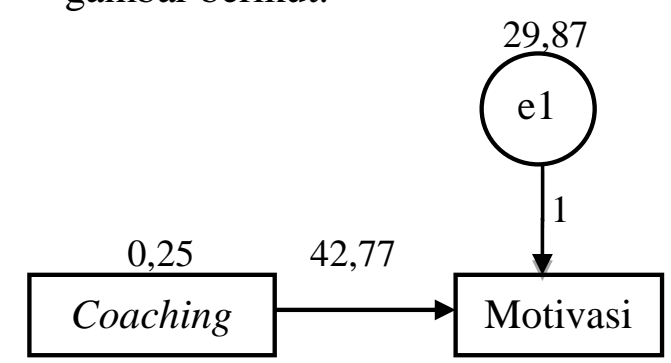

Gambar 1. Hubungan Empirik Sub Struktur 1, Pengaruh Variabel $\mathrm{X}$ Terhadap Y1

\section{b. Uji Secara Individual Sub- Struktur 2}

Hipotesis penelitian yang akan diuji dirumuskan sebagai berikut:

Ho: $($ py2y1) $=0$ atau motivasi kerja tidak memiliki pengaruh positif dan signifikan langsung terhadap kinerja perawat.

Ha: (py2y1)> 0 atau motivasi kerja memiliki pengaruh positif dan signifikan langsung terhadap kinerja perawat.

Hasil pengolahan data sub struktur 2, dimana nilai estimasi yang diilustrasikan antara motivasi dan kinerja adalah sebesar 0,454 sementara itu untuk nilai korelasi regresi adalah sebesar 0,848 (bobot regresi standar dengan model nomor 1-standar). Nilai varian adalah sebesar 487,1 dengan e1 sebesar 39,28 sedangkan nilai satuan kuadrat korelasi berganda adalah sebesar 0,719 (kuadrat korelasi berganda dengan model grup 1standar).

Nilai signifikansi $(\mathrm{Sig}=0,000)$ yang diperoleh dalam koefisien substruktur 2 yang lebih kecil dari nilai probabilitas $(0,05)$, menunjukkan bahwa Ha diterima dan Ho ditolak yang berarti jalan koefisien analisis bersifat signifikan. Jadi dapat disimpulkan bahwa motivasi kerja (Y1) memiliki pengaruh positif dan signifikan langsung terhadap kinerja perawat (Y2) dengan koefisien jalur sebesar 0,848 dan dengan nilai $\mathrm{R}^{2}$ yaitu sebesar $71,9 \%$.

Hubungan empirik sub-struktur 2 adalah efek dari variabel Y1 ke Y2 yang dapat dilihat di bawah ini:

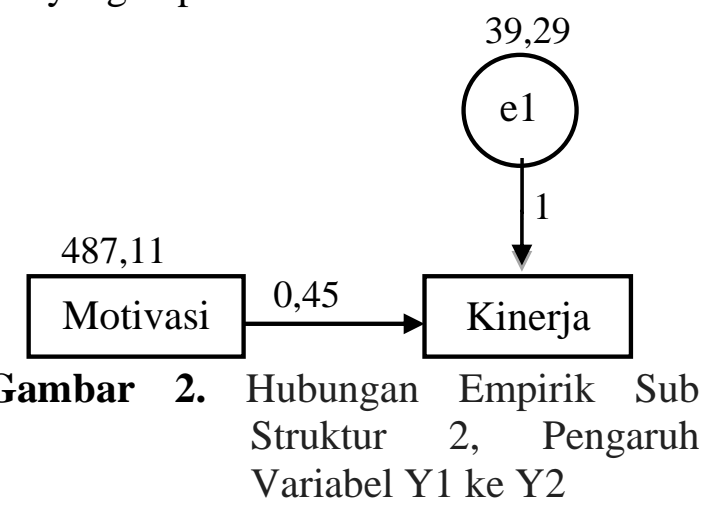
c. Uji Secara Individual Sub- Struktur 3


Hipotesis penelitian yang akan diuji dirumuskan ke dalam hipotesis statistik sebagai berikut:

Ho: $($ py $2 x)=0$ atau coaching tidak memiliki efek positif dan signifikan langsung pada kinerja perawat.

Ha: $(p y 2 x)>0$ atau coaching memiliki efek positif dan signifikan langsung terhadap kinerja perawat.

Hasil Sub Data Pengolahan Struktur 3, yang menggambarkan nilai estimasi antara variabel coaching dan kinerja adalah sebesar 21,80 sementara untuk nilai korelasi regresi adalah sebesar 0,922 (berat regresi standar dengan nomor kelompok 1model standar). Nilai varians adalah sebesar 0,250 dan dengan nilai e1 sebesar 21.00. Sedangkan, nilai satuan kuadrat korelasi berganda adalah sebesar 0,850 (kuadrat korelasi berganda dengan model nomor 1 kelompok-standar).

Hasil perhitungan menunjukkan bahwa nilai signifikansi $(\operatorname{Sig}=0,000)$ pada koefisien sub-struktur 3 dimana nilainya lebih kecil dari nilai probabilitas $(0,05)$, ini menunjukkan bahwa Ha diterima dan Ho ditolak yang berarti koefisien analisis jalur adalah penting. Jadi dapat disimpulkan bahwa variabel coaching berpengaruh positif dan signifikan langsung terhadap variabel kinerja dengan nilai koefisien jalur sebesar 0,922 dengan pengaruh yang besar sesuai nilai $\mathrm{R}^{2}$ yang dihasilkan yaitu sebesar $85,0 \%$.

Berikut ini adalah hubungan empirik sub-struktur 3 yang merupakan pengaruh dari variabel $\mathrm{X}$ ke Y2:

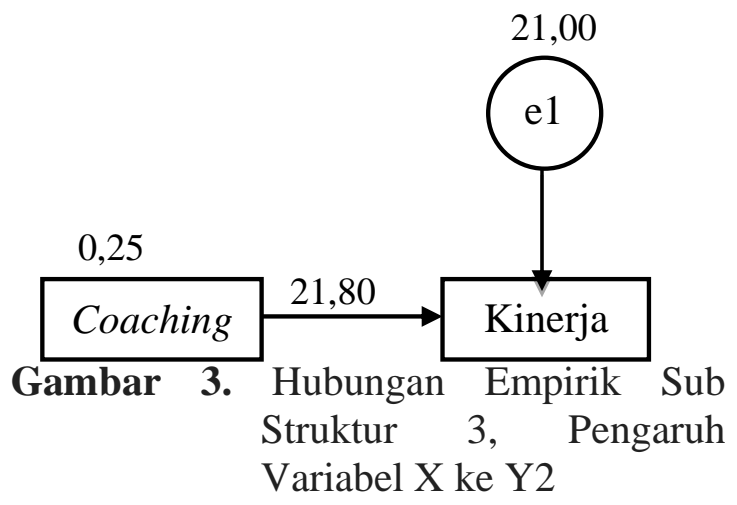

Dari hasil koefisien jalur pada sub struktural 1, sub struktural 2 dan sub struktural 3, dapat digambarkan sebagai keseluruhan hubungan sebab akibat empiris antara variabel $\mathrm{X}$ ke $\mathrm{Y} 1$ dan Y2. Pengaruh coaching bersama (X1) pada motivasi kerja (Y1 ) dan kinerja perawat (Y2) ditunjukkan dengan perhitungan nilai koefisien determinasi (R2) yang diperoleh sebesar 0,704. Koefisien jalur variabel lain di luar coaching (X1) pada motivasi kerja (Y1) dan kinerja perawat (Y2) diperoleh pada nilai 0,296. Dari hasil perhitungan diperoleh koefisien jalur dapat dihitung banyak variabel pengaruhhipotesis yang dapat dijelaskan hubungan efek $\mathrm{X}$ pada $\mathrm{Y} 1$ dan $\mathrm{Y} 2$ yaitu sebagai berikut: $\quad 16,34$

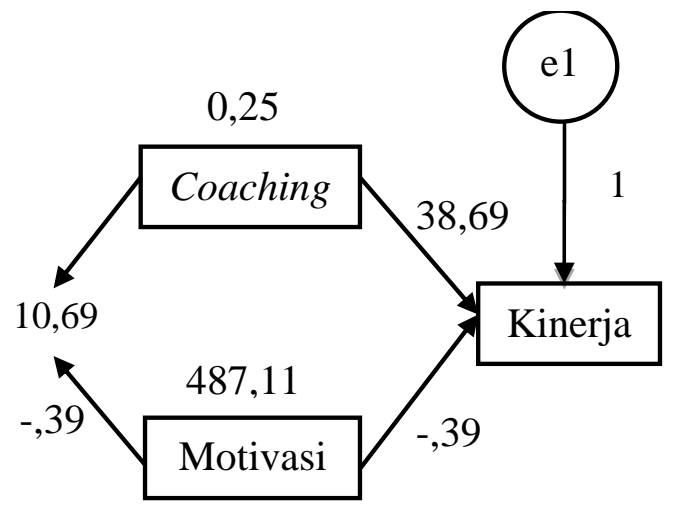

Gambar 4. Diagram Garis Pengaruh X ke Y1 dan Y2 
Dengan memperhatikan gambar di atas, garis persamaan adalah sebagai berikut:

$$
\mathrm{X}=42,77+38,69 \mathrm{Y} 1 \mathrm{Y} 2+\varepsilon .
$$

Berikut ini adalah struktur keseluruhan hubungan empiris, pengaruh variabel $\mathrm{X}$ terhadap $\mathrm{Y} 1$ dan Y2.

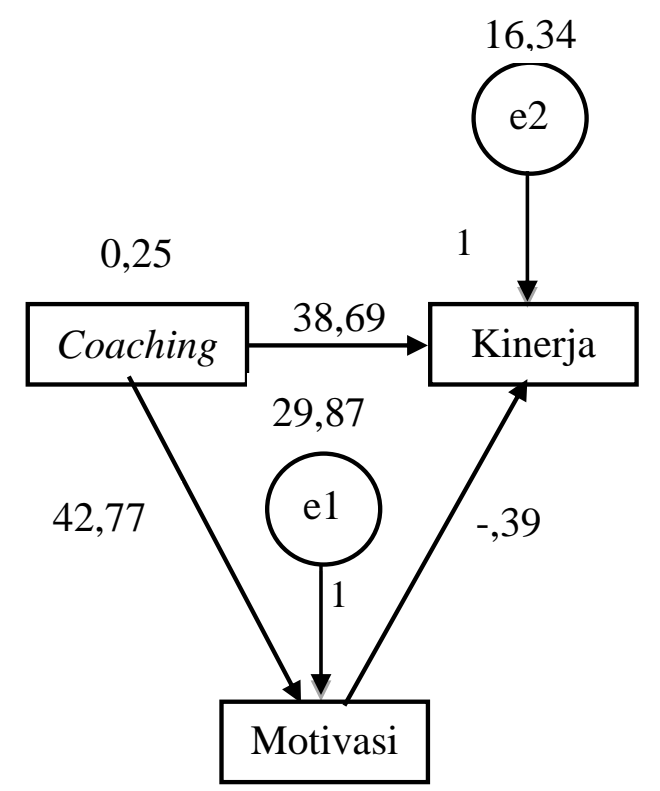

Gambar 5. Diagram Garis Pengaruh $X$ ke Y1 dan Y2

\section{PEMBAHASAN}

Secara keseluruhan dari hasil analisis data statistik membuktikan bahwa ada korelasi positif dan signifikan antara variabel coaching pada motivasi kerja dan kinerja perawat yang menunjukkan pengaruh langsung dari nilai standar yaitu 0,704 dengan nilai P: $0,000<0,05$. Hal Ini menunjukkan hubungan antara administrasi (proses manajemen) dan dampak positif coaching perawat untuk meningkatkan motivasi dan kinerja. Lebih lanjut, hal ini juga dapat dilihat dari perbedaan rata-rata jawaban kuesioner motivasi dan kinerja keperawatan pada pre-test dan post-test. Nilai rata-rata dari variabel motivasi kerja pada pengukuran pre-test adalah sebesar 56,60, nilai ini meningkat setelah sesi coaching dilakukan yaitu menjadi sebesar 100,93 dalam pengukuran post-test. Untuk variabel kinerja perawat, nilai rata-rata pengukuran pre-test adalah sebesar 27,40 dan meningkat setelah sesi coaching dilakukan yaitu menjadi sebesar 55,53 dalam pengukuran post-test. Sementara itu, nilai koefisien determinasi dari coaching berpengaruh terhadap motivasi kerja dan kinerja perawat sebesar $\mathrm{R}^{2}=0,544$ atau $54,4 \%$; ini menunjukkan bahwa tingkat motivasi dan kinerja perawat $54,4 \%$ disebabkan oleh coaching; sedangkan sisanya $45,6 \%$ ditentukan oleh variabel lain yang tidak tercakup dalam model penelitian ini; misalnya: mentoring, counseling, training dan lain-lain.

Di antara pengaruh coaching terhadap motivasi kerja dan kinerja perawat adalah ternyata pengaruh coaching terhadap motivasi kerja memiliki pengaruh yang lebih dominan, hal ini karena koefisien jalur coaching pada motivasi kerja $(\mathrm{c}=0,969)$ lebih besar daripada koefisien jalur coaching pada kinerja perawat $(c=0,922)$. Implikasi untuk meningkatkan kinerja karyawan adalah perlu dilakukannya upaya fokus terhadap SDM RS agar dapat meningkatkan motivasi karyawan baik melalui upaya coaching maupun upaya pemberdayaan lainnya. Peningkatan motivasi kerja dapat dilakukan dengan memperhatikan aspek motivasi karyawan yang masih tergolong rendah. Amanah Undang-Undang No. 36 tahun 2014 tentang Tenaga Kesehatan menyatakan bahwa tenaga kesehatan memiliki peran penting untuk meningkatkan kualitas pelayanan kesehatan kepada masyarakat. Petugas kesehatan seperti perawat 
memiliki posisi penting dalam menghasilkan layanan kesehatan berkualitas di rumah sakit. Berdasarkan Undang-Undang No. 38 tahun 2014 tentang Keperawatan menyatakan bahwa untuk memajukan kesejahteraan umum sebagai salah satu tujuan nasional perlu diselenggarakan pembangunan kesehatan; yang diwujudkan melalui penyelenggaraan pelayanan kesehatan, termasuk pelayanan keperawatan yang dilakukan secara bertanggung jawab, akuntabel, berkualitas, aman dan terjangkau oleh perawat yang memiliki kompetensi, kewenangan, etika dan moral yang tinggi. Dalam elemen penilaian akredistasi RS, setiap staf memperoleh pendidikan dan pelatihan in-service yang berkelanjutan, maupun yang lain untuk menjaga atau meningkatkan keterampilan dan pengetahuannya (Instrumen Standar Akreditasi RS, 2012).

Hal ini tentu mempunyai satu tujuan utama yaitu untuk meningkatkan kualitas pelayanan kesehatan yang dapat meningkatkan derajat kesehatan masyarakat. Tetapi tantangannya adalah rumah sakit yang merupakan lembaga pelayanan kesehatan harus memiliki manajemen yang baik untuk menyelesaikan kompleksitas manajemen yang ada (Bansal, Pratina \& Kendall, 2000) terutama terkait dengan model pengelolaan terhadap SDM-nya.

Dalam rangka peningkatan kualitas SDM, menurut Whitemore (2009) salah satu metode yang dapat digunakan oleh seorang manajer untuk melakukan bimbingan, pendidikan dan pelatihan adalah coaching. Coaching adalah salah satu cara atau kunci untuk membuka potensi seseorang untuk memaksimalkan kinerja mereka. Inti dari coaching adalah memberdayakan orang untuk memfasilitasi pembelajaran mandiri, pertumbuhan pribadi, dan peningkatan kinerja (Kaswan, 2012). Pemimpin dapat menggunakan coaching sebagai alat utama untuk pengembangan kepemimpinan dan manajemen untuk membantu staf memiliki nilai dan potensi yang tinggi, mengembangkan kapasitas untuk menangani, mengubah dan memberikan dukungan dalam memenuhi tuntutan peran mereka. Dalam hal ini akan sulit untuk menemukan organisasi komersial sukses yang tidak menggunakan coaching sebagai pendekatan untuk memberdayakan SDM (Jones, Woods\& Guillaume, 2016). Selain itu, dinyatakan oleh Gillespie (2011) mengenai praktik coaching ini bahwa sebesar $10 \%$ pengembangan bakat diri datang melalui pelatihan, sebesar $20 \%$ datang melalui coaching dan sebesar $70 \%$ datang melalui pengalaman. Metode coaching dapat meningkatkan kompetensi dan akuntabilitas sumber daya manusia di rumah sakit tetapi harus memperhatikan tingkat kebutuhan SDM di setiap tingkatan. Menurut Maslow, kebutuhan yang diinginkan seseorang bersifat berjenjang, artinya ketika persyaratan pertama telah dipenuhi, maka kebutuhan untuk tingkat kedua akan menjadi yang utama, seperti halnya setelah kebutuhan tingkat kelima. Motivasi seseorang dipengaruhi oleh dua dimensi yaitu dimensi internal dan eksternal. Seseorang yang memiliki motivasi kerja yang tinggi akan bekerja dengan baik, memiliki rasa tanggung jawab atas tugas yang diberikan dan selalu berusaha untuk menghasilkan kinerja yang baik. Salah satu cara untuk meningkatkan kinerja adalah dengan diberikannya coaching kepada perawat dan selanjutnya mengukur kembali kemajuan pekerjaan yang mereka lakukan. 
RS dengan Pola Pengelolaan Keuangan di Badan Layanan Umum Daerah (BLUD) memiliki tanggung jawab agar dapat meningkatkan kinerja pelayanan kepada masyarakat dengan prinsip efisiensi dan produktivitas, tentunya kondisi ini sangat dipengaruhi oleh peningkatan kinerja perawat tersebut. Selain itu standar akreditasi RS tentang kualifikasi dan pendidikan staf dalam bentuk pelatihan sebagai kegiatan yang diperlukan untuk meningkatkan kualitas dan keselamatan pasien, bertujuan untuk menjaga kinerja perawatyang baik/ dapat diterima, untuk mengajarkan keterampilan baru dan memberikan pelatihan dan pendidikan untuk setiap perawat dan juga untuk memajukan RS yang berlanjut dalam memenuhi kebutuhan pasien sehingga terjadi peningkatan kualitas pelayanan yang berdampak pada peningkatan derajat kesehatan masyarakat. Manajemen yang efektif sangat penting dimiliki untuk dapat menciptakan sistem pelayanan kesehatan berkinerja tinggi. Kurangnya keterampilan manajemen adalah penyebab rendahnya kinerja (Linnander, Mantopoulos, Allen \& Nembard, 2017). Kualitas pelayanan kesehatan dan keselamatan pasien adalah hasil dari proses manajemen yang paling utama di rumah sakit dan banyak model atau kerangka kerja yang dikembangkan untuk meningkatkan manajemen RS (Friesner, Neufelder, Raisor \& Bozman, 2009). Praktik manajemen di rumah sakit harus memberi manfaat bagi institusi seperti operasional yang efisien, manajemen pasien yang unggul, administrasi yang dapat dikontrol, dan peningkatan profit (Olamide, Elegbede \& Ogunseye, 2015). Orang-orang diharapkan melakukan semua fungsi manajemen untuk meningkatkan kapasitas dan kemampuan sebagai persyaratan dasar untuk memiliki hasil terbaik dari pelayanan RS.

Praktek manajemen yang baik sebagai hasil dari coaching akan mampu menyelesaikan tugas yang sulit dan ini dapat didedikasikan untuk perawat yang mengalokasikan dan mengawasi penggunaan sumber daya dan akhirnya dapat mencapai tujuan dengan melibatkan semua fungsi terkait dan mengoordinasikan berbagai sumber daya tersebut untuk pencapaian kinerja (Bansal, Pratina\& Kendall, 2000). Coaching dapat menjadi metode atau pendekatan yang digunakan untuk meningkatkan motivasi perawat dan memiliki kemampuan untuk menemukan serta mengidentifikasi masalah, kemudian belajar untuk menyelesaikannya sehingga akhirnya mendapatkan kinerja yang maksimal.

\section{KESIMPULAN DAN SARAN}

Coaching dapat meningkatkan potensi seseorang dan secara langsung mempengaruhi secara positif dan signifikan terkait dengan motivasi kerja. Selain itu coaching tidak hanya bertujuan meningkatkan potensi pengaruh langsung seseorang secara positif dan signifikan terhadap kinerja perawat, tetapi juga bertujuan meningkatkan potensi pengaruh langsung seseorang secara positif dan signifikan terhadap kinerja perawat melalui motivasi kerja. Proses manajerial seperti perencanaan, implementasi dan evaluasi dengan pendekatan pemberdayaan atau coaching ini dapat meningkatkan kualitas dan akuntabilitas kinerja staf (perawat) sehingga berdampak pada meningkatnya kinerja RS secara keseluruhan. Dalam rangka memberdayakan staf RS, terutama pada poin kualifikasi staf dan pelatihan 
sebagaimana diisyaratkan berdasarkan instrumen akreditasi maka untuk meningkatkan kualitas layanan kesehatan di masa mendatang perlu memasukkan nomenklatur coaching dalam undangundang atau kebijakan lain seperti adanya media yang memberikan pendidikan dan pelatihan kepada perawat dan tenaga kesehatan lainnya diikuti dengan perencanaan untuk berkomitmen dalam menjalankan program coaching secara teratur terhadap program pemberdayaan sehingga motivasi staf dan peningkatan kinerja RS dapat diwujudkan sebagai syarat utama dalam rangka peningkatan derajat kesehatan masyarakat yang setinggi-tingginya.

\section{DAFTAR RUJUKAN}

Bansal, Pratina, Kendall R. (2000).Why Companies Go Green: A Model Of Ecological Responsiveness. Journal Academy of Management, Volume 43 Issue 4.

Friesner, D., Neufelder, D., Raisor., \& Bozman, C.S. (2009). How To Improve Patient Satisfaction When Patients Are Already Satisfied: A Continuous Process Improvement Approach. Hospital Topics:Winter.

Gillespie J. (2011). Leadership transformation powers growth for firms in Asia. Journal The Korn; Ferry Institute.

Hartono, B. (2016). Pemberdayaan SDM Melalui Metode Coaching (Seri HospitalCoaching).

http://www.harianbernas.com/beri ta-17788-Pemberdayaan-SDM-

Melalui-Coaching-Seri.html

Diperoleh pada tanggal 10 Agustus 2016.
Joint Commission International. (2002). Join Commission Accreditation of Healthcare Organization. United State of America.

Jones, R.J., Woods, S.A. \& Guillaume, Y.R. (2016). The Effectiveness of Workplace Coaching: A MetaAnalysis of Learning and Performance Outcomes From Coaching. Journal of Occupational and Organizational Psychology. Volume 89 No. 2.

Kaswan. (2012). Coaching Dan Mentoring. Alfabeta: Bandung.

Kohn, L. T. \& Corrigan, J. M. (2000).To Err Is Human: Building A Safer Health System. Institute of Medicine. National Academies Press:United State of America.

Linnander, E. L, Mantopoulos J. M., \&Allen N. N. (2017) Professionalizing Healthcare Management: A Descriptive Case Study. Journal Health Policy Management.

Notoatmodjo, S.(2012). Metode Penelitian Kesehatan Edisi Revisi. Rineka Cipta: Jakarta.

Olamide, A. W. \& Ogunseye, A. A. (2015). Design and Implementation of Hospital Management System Using Java. IOSR Journal of Mobile Computing \& Application. Available from http://www.iosrjournals.org

Theeboom, T., Beersma, B. \& Van Vianen, A. (2013). Does coaching work? A meta-analysis on the effect of coaching on individual level outcomes in an organizational context. The Journal of Positive Psychology, Volume 9 No. 1. 
Undang-Undang Nomor 38 Tahun 2014

Tentang Keperawatan.

Undang- Undang Nomor 36 Tahun 2014

Tentang Tenaga Kesehatan.

Whitemore, J. (2009). Coaching For

Performance, Fourth Edition.

Nocholas Brealey Publisihing:

London-Boston. 